\title{
A thermomechanical modelling of continuous casting to master steel slabs internal soundness and surface quality*
}

\author{
N. Triolet, M. Bobadilla (Arcelor Research) \\ M. Bellet (École des Mines de Paris, Cemef) \\ L. Avedian (Arcelor, Sollac Atlantique) \\ P. Mabelly (Arcelor, Sollac Méditerranée)
}

The development of high tensile strength steels with higher levels of alloying elements needs the implementation of operating means in the continuous casting machine to master slabs internal soundness and surface quality. In order to define optimal process parameters, according to the characteristics of the different continuous casting machines, and to optimize the revamping of older equipment, thermomechanical modelling of the steel slab behaviour during casting has been carried out. This paper presents the results of simulations performed to check the potential of this modelling.

\footnotetext{
* Subject of a presentation at the 2004 ATS International Steelmaking Conference (Paris, December 9-10, 2004, Session 14).

(C) La Revue de Métallurgie 2005.
}

\section{INTRODUCTION}

High tensile strength steels are currently being developed for automotive applications. These steels contain a large amount of alloying elements, which lead to both increased segregation and cracking sensitivity.

During casting, the bulging of the slab along the support rolls induces cyclic strains and stresses both in the mushy zone and in the solid shell. These deformations could be responsible for surface quality issues like corner cracks, and internal defects like hot tearing and macrosegregation (1). Indeed, if the slab bulging induces tension into the mushy zone close to the end of solidification, the last-residual-enriched liquid is sucked and flows across the dendritic solid network $(2,3)$. The solidification of this segregated liquid in the centre of the product leads to a detrimental axial macrosegregation, as outlined for instance by Nippon Steel (4), which indicates that axial macrosegregation intensifies when the amount of bulging exceeds $200 \mu \mathrm{m}$. Moreover, if the dendritic network is unable to sustain the tensile stresses, cracks may be observed. This means that we need to know slab strains and stresses during casting, and to get mechanical and metallurgical criteria in order to be able to predict the damage of the solid phase into the mushy zone (5), and also in the critical interval for ductility, which is typically between 700 and $1,000^{\circ} \mathrm{C}(6)$.

In order to define optimum casting conditions allowing maximum casting speed with suitable internal soundness and surface quality, a macroscopic thermomechanical model of steel slab continuous casting has been developed by CEMEF. This is a useful tool to help the manufacturers to modify the design of their machines (curvature of bending and unbending zones, roll dimensions and pitch...) and to help the steelmakers to adapt their casting conditions (casting velocity, cooling strategy...) according to the cast steel grade properties. We will see hereafter the influence of these parameters on the slab bulging.

First, the original global, non steady-state approach and the model used for the calculations are presented. The interested reader can refer to previous publications, where it was largely detailed $(7,8,9)$. In a second part, we focus on the calculations carried out by Arcelor Research to assess the potential of this modelling, as well as on the operational results. The effects of roll arrangement, casting speed and heat transfer on the slab bulging were investigated. 


\title{
Une modélisation thermomécanique de la coulée continue pour maîtriser la santé interne et la qualité de surface des brames d'acier
}

\author{
N. Triolet, M. Bobadilla (Arcelor Research) \\ M. Bellet (École des Mines de Paris, Cemef) \\ L. Avedian (Arcelor, Sollac Atlantique) \\ P. Mabelly (Arcelor, Sollac Méditerranée)
}

Les aciers à très haute résistance développés pour des applications automobiles peuvent être très chargés en éléments d'alliage, ce qui les rend sensibles à la ségrégation et à l'endommagement au cours de l'opération de coulée. Ces problèmes de santé interne résultent du gonflement de la brame entre les rouleaux du système de soutien. Ce gonflement induit en effet des contraintes et des déformations périodiques dans la zone pâteuse et dans la coque solide. Pour être en mesure de définir les conditions de coulée optimales permettant d'assurer une productivité maximale et d'obtenir des produits de qualité, une modélisation thermomécanique $2 \mathrm{D}$ et $3 \mathrm{D}$ de la coulée continue de brames d'acier, à l'échelle macroscopique, a été développée. L'originalité de cette simulation repose sur le calcul du gonflement sur toute la longueur de la machine de coulée, en fonction :

- des propriétés de l'acier coulé;

- des paramètres process (vitesse de coulée, stratégie de refroidissement...);

- des spécificités de la machine de coulée : profils de cintrage / décintrage, diamètre et pas des rouleaux, réduction douce mécanique, position des sprays $d u$ système de refroidissement, etc.

Les potentialités de cette approche ont été démontrées dans des configurations de coulée industrielles. Les résultats obtenus montrent que :

- la modélisation permet de décrire le fluage de la coque solide entre les rouleaux du système de soutien, sous l'action de la pression ferrostatique exercée par le cour liquide;

- la confrontation des résultats avec des mesures de gonflement et d'autres résultats de simulation est satisfaisante ;

- la modélisation reproduit correctement l'influence des paramètres process sur le gonflement de la brame.
La validation quantitative du modèle sera établie par comparaison des résultats numériques à des mesures réalisées sur le pilote de coulée continue de bramettes d'Arcelor Research. Notre objectif final est d'être capable de prévoir la formation de la macroségrégation axiale en fonction des propriétés de l'acier coulé et des paramètres process. Ceci doit nous aider à définir les conditions optimales pour mettre en place une réduction douce mécanique sur une ligne de coulée industrielle. Pour atteindre cet objectif, il est nécessaire de décrire correctement le comportement de la zone semi-solide. Pour cela, une approche diphasique est en cours de développement dans notre modèle 2D. Les échanges d'énergie, de masse, de quantité de mouvement et de soluté entre la phase liquide et la phase solide sont pris en compte. Nous simulerons ainsi les écoulements de la phase liquide ségrégée en éléments d'alliage à travers la phase solide de la zone pâteuse sous l'effet du gonflement périodique de la brame entre les rouleaux du système de soutien.

Le modèle $3 D$ sera exploité pour traiter des problèmes de qualité de surface. Cette approche est nécessaire pour prévoir, par exemple, la formation de criques d'angle. De plus, nous avons commencé à développer une modélisation $3 D$ du comportement thermomécanique de la peau qui se solidifie en lingotière de coulée continue. Elle traite de façon couplée les écoulements turbulents de métal liquide surchauffé, le comportement thermomécanique de la peau qui se solidifie et la dilatation de la lingotière. 


\section{AN ORIGINAL GLOBAL, NON STEADY-STATE APPROACH}

The global, non steady-state approach is illustrated in figure 1. Starting from an initial mesh representing a small amount of steel at the top of the machine, the advancing of the product is simulated by imposing to the lower surface a condition of bilateral contact with a rigid extraction tool, which moves at the nominal casting speed. On the contrary, the upper surface remains fixed : this means that the mesh volume enlarges continuously at each time step. This method requires solving a transient thermomechanical problem, which is assumed to converge towards the steady-state regime. It was implemented in $\mathrm{R}^{2} \mathrm{SOL}^{\circledR}$ and $\mathrm{TherCast}^{\circledR}$ softwares, which are, respectively, $2 \mathrm{D}$ and $3 \mathrm{D}$ finite element modelling tools.

The mesh management is a key point of the method. The nodes belonging to the upper surface remain fixed, while all other nodes move with the same speed as the product. Consequently, the first row of elements near the top surface undergoes continuous elongation. To prevent mesh degeneracy, a periodic remeshing operation is carried out, in which most nodes are untouched, except those located near the top surface. During remeshing, some new nodes are added in this region. It is also possible with the same software to carry out a classical non-steady slice modelling as it has been achieved by Thomas et al. (10), or Pascon (11) : the upper surface may become a free surface, which is the upper surface of the slice, allowed to move down.
At this stage, it is important to detail some assumptions :

- First, the model is focused on the thermomechanical stress-strain analysis, while the fluid flow occurring in the liquid pool is ignored. This is a rough approximation in the mould region, but we assume that it has no major impact on the thermomechanical state in the secondary cooling, which is the effective aim of this work.

- For the moment, the mushy zone is considered as one homogeneous phase. Some work is in progress in order to model the mushy zone as a two-phase continuum, with an effective distinction between the motion of the liquid phase and of the solid phase (12). In this modelling, the exchange of solute, mass, energy and momentum are taken into account between both phases.

\section{THE THERMOMECHANICAL MODELLING}

\section{Heat transfer problem}

The thermal problem is based on the resolution of the heat transfer equation, which is the general energy conservation equation :

$$
\rho(T) \frac{d H(T)}{d t}=\nabla \cdot(\lambda(T) \nabla T)
$$

$\lambda\left(\mathrm{W} / \mathrm{m} /{ }^{\circ} \mathrm{C}\right)$ denotes the thermal conductivity, $\rho\left(\mathrm{kg} / \mathrm{m}^{3}\right)$ the density and $\mathrm{H}(\mathrm{J} / \mathrm{kg})$ the specific enthalpy which can be defined as :

$$
H(T)=\int_{T_{0}}^{T} C_{p}(\tau) d \tau+\left(1-g_{s}(T)\right) L
$$

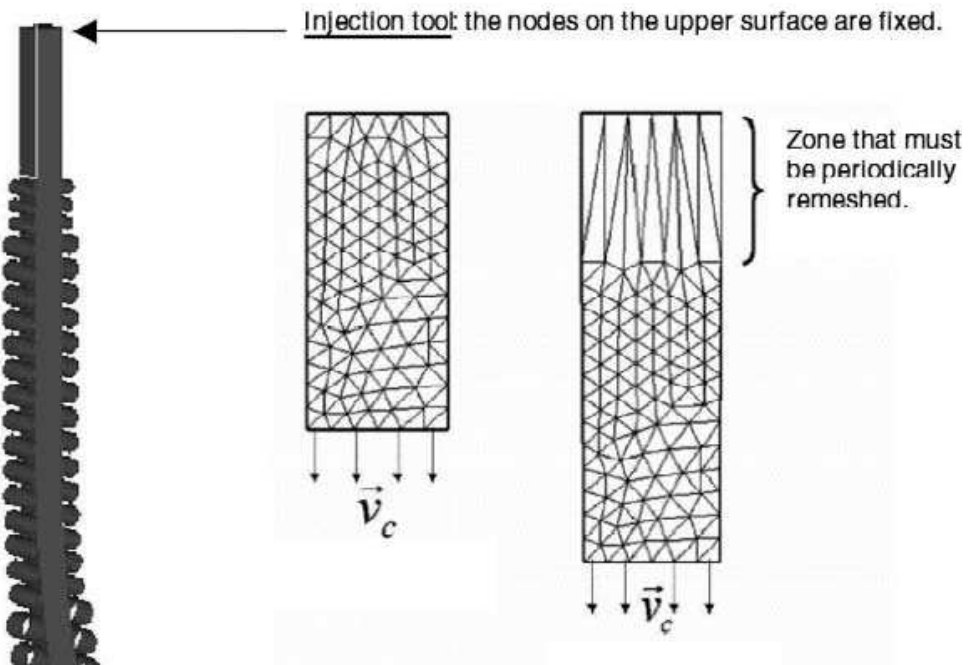

$\mathrm{T}_{0}\left({ }^{\circ} \mathrm{C}\right)$ is an arbitrary reference temperature, $\mathrm{C}_{\mathrm{p}}$ $\left(\mathrm{J} / \mathrm{kg} /{ }^{\circ} \mathrm{C}\right)$ the specific heat, $\mathrm{g}_{\mathrm{s}}$ the volume fraction of solid and $\mathrm{L}(\mathrm{J} / \mathrm{kg})$ the specific latent heat of fusion. In the one-phase modelling, $\mathrm{g}_{\mathrm{s}}(\mathrm{T})$ is previously calculated using the microsegregation model PTIMEC_CEQCSI (13).

The temperature is prescribed onto the top surface of the mesh : $\mathrm{T}=\mathrm{T}_{\mathrm{imp}}$. We assume an adiabatic condition on the extraction tool $:-\lambda \nabla T . \mathbf{n}=0$. On the lateral surface of the mesh, the thermal boundary conditions are averaged on successive zones :

- In the mould, heat flux is imposed uniformly : $-\lambda \nabla$ T.n $=\Phi_{\text {imp }} . \mathbf{n}$ denotes the outward normal unit vector. We do not take into account a possible air gap at slab/mould interface on heat release. This hypothesis is justified by the fact that we focus this work on the secondary cooling. 
- In the secondary cooling, we have the possibility to impose two kinds of averaged boundary conditions on successive zones defined between two metallurgical lengths :

- Average convection : $-\lambda \nabla \mathrm{T} . \mathbf{n}=\mathrm{h}_{\mathrm{zone}}\left(\mathrm{T}-\mathrm{T}_{\text {ext }}\right)$, where $\mathrm{h}_{\text {zone }}\left(\mathrm{W} / \mathrm{m}^{2} /{ }^{\circ} \mathrm{C}\right)$ is the heat transfer coefficient, and $\mathrm{T}_{\text {ext }}$ is the external temperature. $\mathrm{h}_{\text {zone }}$ is uniform and constant on each zone ;

- Radiation : $-\lambda \nabla$ T.n $=\varepsilon_{\mathrm{r}} \sigma_{\mathrm{r}}\left(\mathrm{T}^{4}-\mathrm{T}_{\mathrm{ext}}^{4}\right)$ where $\varepsilon_{\mathrm{r}}$ is the steel emissivity and $\sigma_{\mathrm{r}}$ the Stephan - Boltzmann constant.

In order to simulate accurately the thermomechanical behaviour of the slab shell in the secondary cooling, we also have the possibility to account for local heat release due to roll contact and spray cooling. Hardin et al (14) have ever used this for instance, which is interesting for the study of transverse corner cracking.

\section{Constitutive equations}

As suggested by Bellet (15), we make a clear distinction between the constitutive equations used for the liquid and mushy state, and those for the solid state. In the one-phase modelling, the liquid and mushy states are modelled using a pure thermo-viscoplastic law, without any elastic contribution. Depending on the solid fraction, the model is either purely Newtonian, or non-linear viscoplastic. A thermoelastic-viscoplastic constitutive law is used to describe the steel behaviour below a coherency temperature (fig. 2). It is more representative of solid-like behaviour. Usually, we assume that the coherency temperature is equal to the temperature of the end of solidification.

\section{Mechanical problem}

At any time, the mechanical equilibrium is governed by the momentum equation : $\nabla \cdot \sigma+\rho \mathbf{g}-\rho \gamma=0$, where $\sigma$ is the Cauchy stress tensor, $\mathbf{g}$ the gravity vector and $\gamma$ the accele-

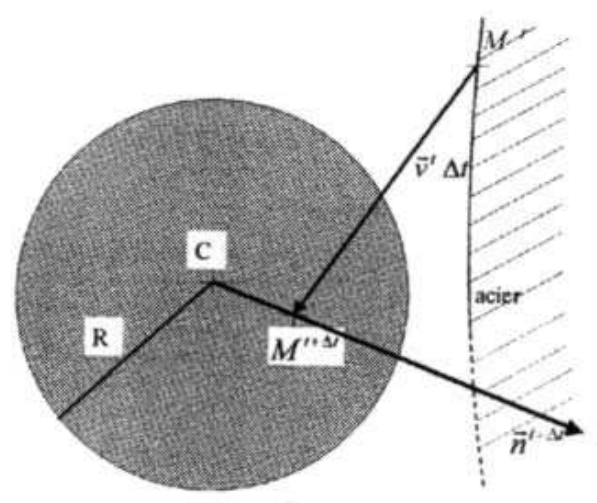

Fig. 3 - Schematic representation of contact penalization to treat the non-penetration of the solidified shell into the rolls.

Fig. 3 - Représentation schématique du contact pénalisé entre la brame et les rouleaux pour contrôler la pénétration de la brame dans les rouleaux.

ration vector. Concerning boundary conditions, the kinetics of the extraction tool is imposed equal to the casting speed. We impose a uniform pressure on the injection tool, which is representative of the local ferrostatic pressure. The free lateral surface is submitted to contact with the support rolls, which are supposed motionless and non-deformable. For the moment, we assume that the slab slides on the rolls. This unilateral contact is modelled by a penalty method. For any boundary point $M$ of the product, and for any roll of centre $C$ and radius $R$, we must have : $C M \geq R$, which is the non-penetration condition (fig. 3). We accept a short penetration of the slab into the rolls of about $0.05 \mathrm{~mm}$. It is of the same order as roll eccentricity.

\section{- THERMOMECHANICAL BEHAVIOUR
OF THE SLAB IN THE SECONDARY \\ THERMOMECHANICAL BEHAVIOUR
OF THE SLAB IN THE SECONDARY COOLING}

\section{Stress distribution calculated into the solid shell}

Some simulations were carried out on Sollac Atlantique No. 23 continuous caster. It is a curved machine, with a radius of $10.5 \mathrm{~m}$. The domain of calculation is a mid-width slice : its thickness is $250 \mathrm{~mm}$. We assume that the deflection of the solid shell at the centre region of the wide face is independent of the slab width. This is the case as soon as the ratio between the slab width and the roll pitch is sufficiently large. The composition of the cast steel grade is indicated in table I. The casting speed is $0.9 \mathrm{~m} / \mathrm{min}$. All the results presented here were obtained for a metallurgical length between 8 and $14 \mathrm{~m}$. 


\section{TABLE I : Composition of the steel grade used} for the simulations.

TABLEAU I : Composition de l'acier utilisé pour les simulations.

\begin{tabular}{|c|c|c|c|c|c|}
\hline & $\mathrm{C}$ & $\mathrm{Si}$ & $\mathrm{Mn}$ & $\mathrm{S}$ & $\mathrm{P}$ \\
\hline $10^{-3} \%$ & 180 & 420 & 1,370 & 9 & 18 \\
\hline
\end{tabular}

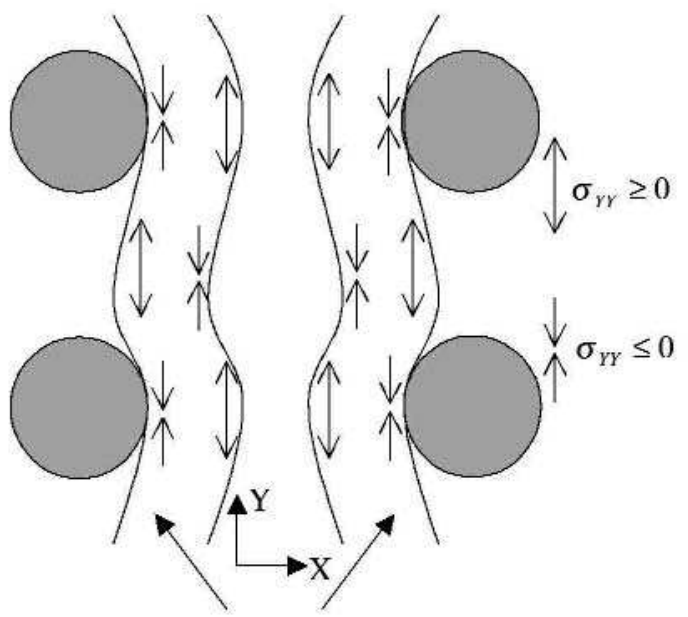

Stccl shell solidificd

Fig. 4 - The longitudinal stress distribution reveals compressive and tensile zones due to the slab bulging between rolls.

Fig. 4 - La carte des contraintes longitudinales montre une sollicitation périodique en traction - compression de la coque solide due au gonflement.
Figure 4 illustrates schematically the longitudinal component of the stress tensor $\sigma_{Y Y}$ into the solid shell. We observe a double periodic alternation of compressive and tensile longitudinal stresses. The quantitative results are indicated in figure 5. On the surface, the slab is in a compressive state at roll contact in the longitudinal direction $\left(\sigma_{Y Y} \approx-20 \mathrm{MPa}\right)$. Conversely, it is in a tensile state on the free surface between rolls $\left(\sigma_{Y Y} \approx 10 \mathrm{MPa}\right)$. If we look at the longitudinal stresses in the solid phase close to the solidification front, we can see that there is also an alternation, but in the opposite sense : it is in a tensile state when passing by a roll $\left(\sigma_{Y Y} \approx 6 \mathrm{MPa}\right)$, while it is in a compressive state between two successive rolls $\left(\sigma_{Y Y} \approx-6 \mathrm{MPa}\right)$.

Concerning the transverse stresses, we observe a large compressive state at roll contact $\left(\sigma_{X X} \approx-20 \mathrm{MPa}\right)$, and a negligible tensile state into the solid shell between rolls $\left(\sigma_{X X} \leq\right.$ $1 \mathrm{MPa})$. The tensile stresses calculated in the transverse direction are clearly smaller than the tensile stresses calculated in the longitudinal direction. This alternation of tensile / compressive stresses in the solid phase results from the bulging of the solid shell between the support rolls. This alternation is also revealed by the symmetric distribution of the shear stresses at roll contact : $\left(\sigma_{\mathrm{XY}} \approx \pm 8 \mathrm{MPa}\right)$ (fig. 6 ). The shear stresses are plotted a few millimetres before and after the roll contact. We observe that rolls induce an inversion of the shear stress orientation into the solid shell.

Consequently, the simulation describes successfully that the solidified shell behaves like a beam resting on the support rolls, which creeps due to ferrostatic pressure loading. Until now, we have assumed that the rolls are perfectly aligned. But if one roll is removed, the bulging and slab strains-stresses are enhanced. Figure 7 shows the large bulging of the slab when one roll was removed at $11 \mathrm{~m}$ of metallurgical length, and the equivalent strain calculated on
SOLLAC Atlantique $-0.9 \mathrm{~m} / \mathrm{mir}$

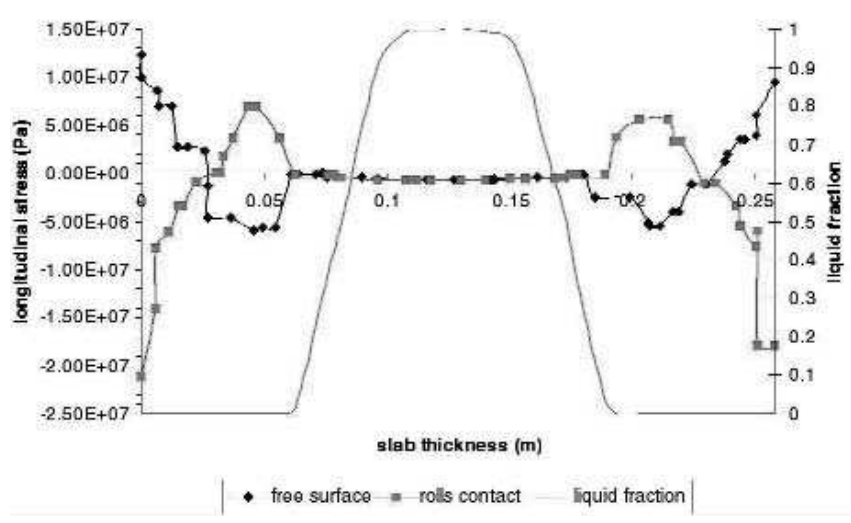

a)
SOLLAC Atlantique $\mathrm{CC23}-0.9 \mathrm{~m} / \mathrm{mir}$

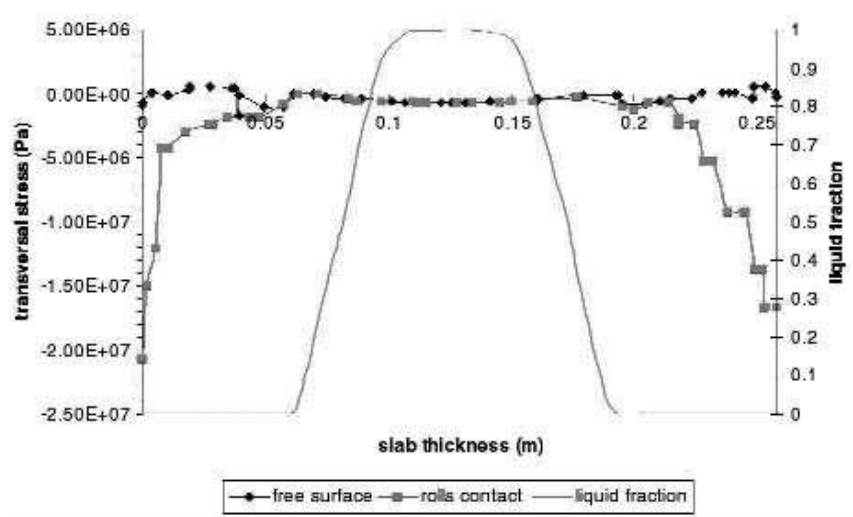

b)

Fig. 5 - Stresses calculated in the slab thickness at roll contact and on the free surface between rolls. (a) Longitudinal stresses. (b) Transverse stresses.

Fig. 5 - Contraintes calculées dans l'épaisseur de la brame dans l'emprise d'une paire de rouleaux et entre deux paires de rouleaux. (a) Contraintes longitudinales. (b) Contraintes transverses. 


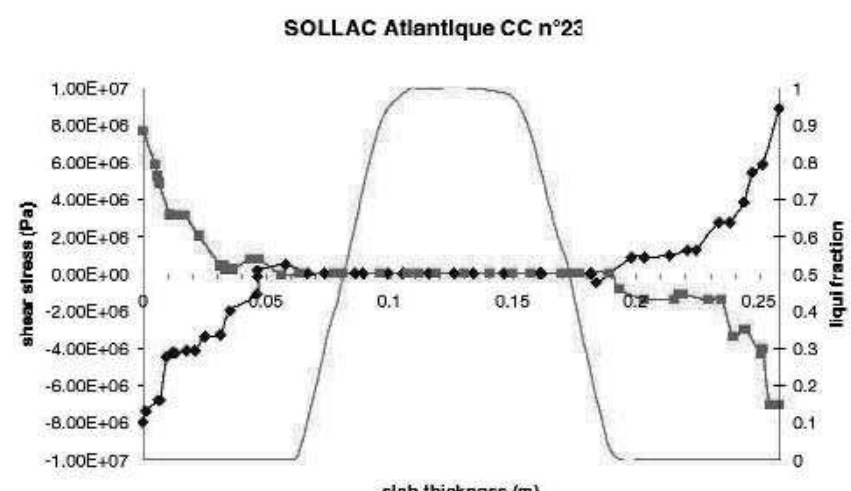

slab thickness (m)

$\rightarrow-$ before roll contact - - after roll contact - liquid fractiol

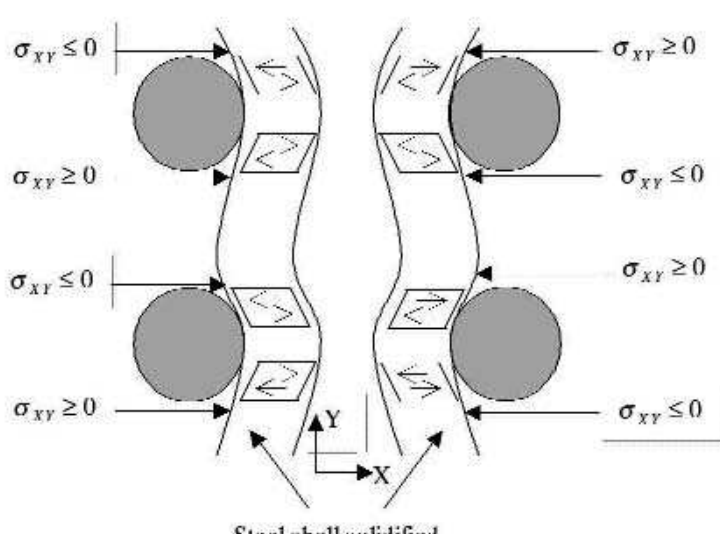

Stecl shell solidified

Fig. 6 - Shear stresses calculated in the slab thickness at roll contact and on the free surface between rolls.

Fig. 6 - Contraintes de cisaillement calculées dans l'épaisseur de la brame dans l'emprise d'une paire de rouleaux et entre deux paires de rouleaux.

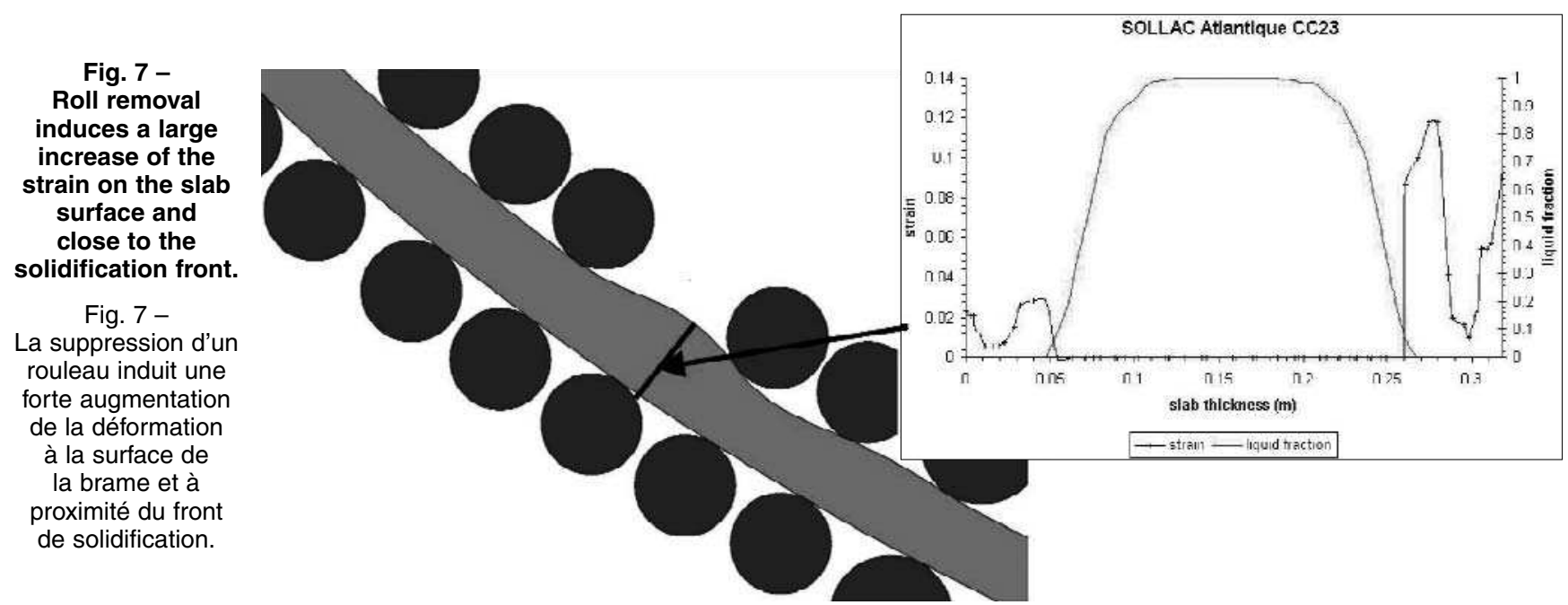

a slab section. The results indicate a clear distinction between the thermomechanical behaviour of the solid shell on both sides. The equivalent strain calculated in the solid shell close to the solidification front, and on the slab surface, is roughly four times more important on the upper side than on the lower side due to the roll removal. This simulation proves the necessity to maintain the caster in an optimal state with few misalignments, and few roll eccentricities, to master a convenient product internal soundness and surface quality with enough productivity. The coupling of this simulation with metallurgical or mechanical criteria will help us to define the critical tolerance for roll misalignment.

\section{Slab bulging between rolls}

As previously mentioned, we use a non-steady approach to carry out the simulation. Figure 8 represents the bulging calculated at $12.3 \mathrm{~m}$ for two casting speeds : $0.9 \mathrm{~m} / \mathrm{min}$ and $1.2 \mathrm{~m} / \mathrm{min}$. It confirms that the bulging converges effecti-
SOLLAC Atlantique CC

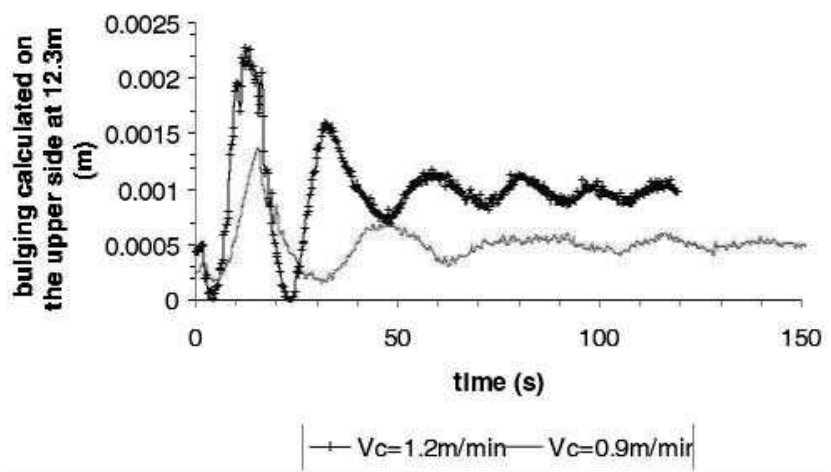

Fig. 8 - The calculated slab bulging converges quickly to a steady state value. It proves the accuracy of the global, non-steady state approach.

Fig. 8 - Le gonflement calculé converge rapidement vers un régime permanent. Ceci prouve la validité de cette approche globale instationnaire. 
TABLE II : Bulging measurements carried out at Sollac Atlantique $\mathrm{CC} 23$ on the upper side, for two casting speeds, and for a metallurgical length between 10 and $12 \mathrm{~m}$.

TABLEAU II : Résultats de mesures de gonflement réalisées à Sollac Atlantique CC23 du côté intrados, pour deux vitesses de coulée, et pour une longueur métallurgique comprise entre 10 et $12 \mathrm{~m}$.

\begin{tabular}{|l|c|c|}
\hline Casting speed & $0.9 \mathrm{~m} / \mathrm{min}$ & $1.2 \mathrm{~m} / \mathrm{min}$ \\
\hline Bulging measurements & $0.6 \mathrm{~mm}$ & $0.9 \mathrm{~mm}$ \\
\hline
\end{tabular}

TABLE III : Bulging predictions calculated for Sollac Atlantique $\mathrm{CC2} 3$ on the upper side, for two casting speeds, and for a metallurgical length between 10 and $12 \mathrm{~m}$.

TABLEAU III : Gonflement calculé sur la CC23 de Sollac Atlantique, du côté intrados, pour deux vitesses de coulée, et à une longueur métallurgique comprise entre 10 et $12 \mathrm{~m}$.

\begin{tabular}{|l|c|c|}
\hline Casting speed & $0.9 \mathrm{~m} / \mathrm{min}$ & $1.2 \mathrm{~m} / \mathrm{min}$ \\
\hline Bulging predictions & $0.2-0.5 \mathrm{~mm}$ & $0.5-1 \mathrm{~mm}$ \\
\hline
\end{tabular}

vely until a steady state value, and proves the accuracy of this approach. A stabilized value is obtained typically after $100 \mathrm{~s}$, corresponding to a casting distance of about $2 \mathrm{~m}$.

Bulging measurements were carried out at Sollac Atlantique (16). The results are indicated in table II. Figure 9 presents the bulging calculated on the upper side for both casting speeds. The roll positions are also represented. A

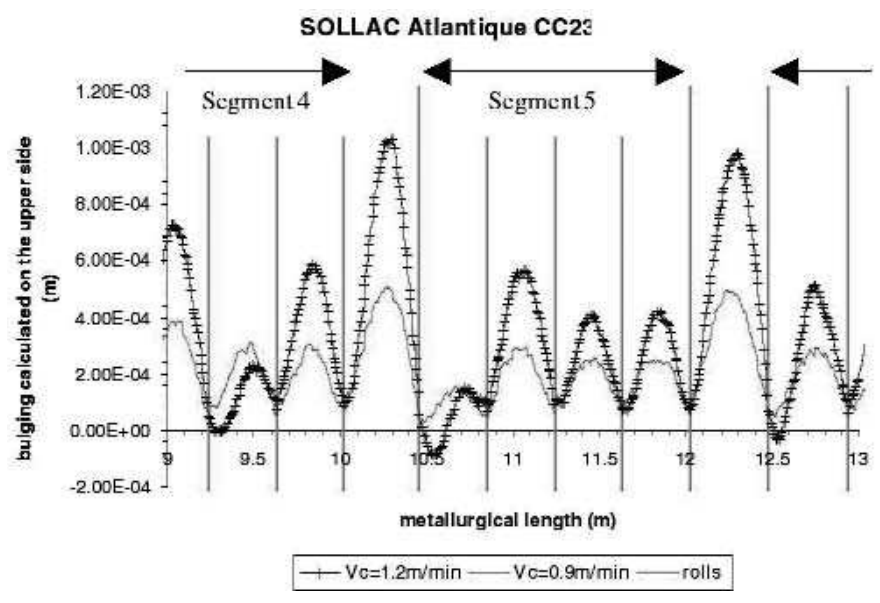

Fig. 9 - Slab bulging calculated for two different casting speeds : $0.9 \mathrm{~m} / \mathrm{min}$ and $1.2 \mathrm{~m} / \mathrm{min}$. The slab bulging increases with an increase of casting speed and roll pitch.

Fig. 9 - Gonflement de la brame calculé pour deux vitesses de coulée : $0.9 \mathrm{~m} / \mathrm{min}$ et $1.2 \mathrm{~m} / \mathrm{min}$. Le gonflement augmente avec la vitesse de coulée et le pas des rouleaux. comparison between table II and table III indicates that the bulging predictions are smaller than the measurements. This could result for instance from a lack of accuracy of the rheological and the thermophysical data used for the simulations. Moreover, we do not know the uncertainty of the bulging measurement device.

At 10.3 and $12.3 \mathrm{~m}$, a local increase of slab bulging, followed by a negative bulging can be observed (fig. 9). This results from an increase of roll pitch, respectively of 0.05 and $0.07 \mathrm{~m}$, due to a transition of segments. This observation shows that we need to reduce the roll pitch in order to reduce the slab bulging and, consequently, improve the slab quality. Moreover, the simulation confirms that bulging increases with casting speed. This results from an increase of $40^{\circ} \mathrm{C}$ of the temperature on the slab surface. From other calculations, we notice that the bulging calculated assuming that all rolls are perfectly aligned (bulging lower than $1 \mathrm{~mm}$ ), is negligible in comparison with the bulging calculated when one roll is misaligned by $5 \mathrm{~mm}$. In this case, the maximal slab bulging is higher than $5 \mathrm{~mm}$. It is also followed by a large negative bulging of $-1.7 \mathrm{~mm}$ (fig. 10). A large roll misalignment has consequences on the slab behaviour on following roll steps.

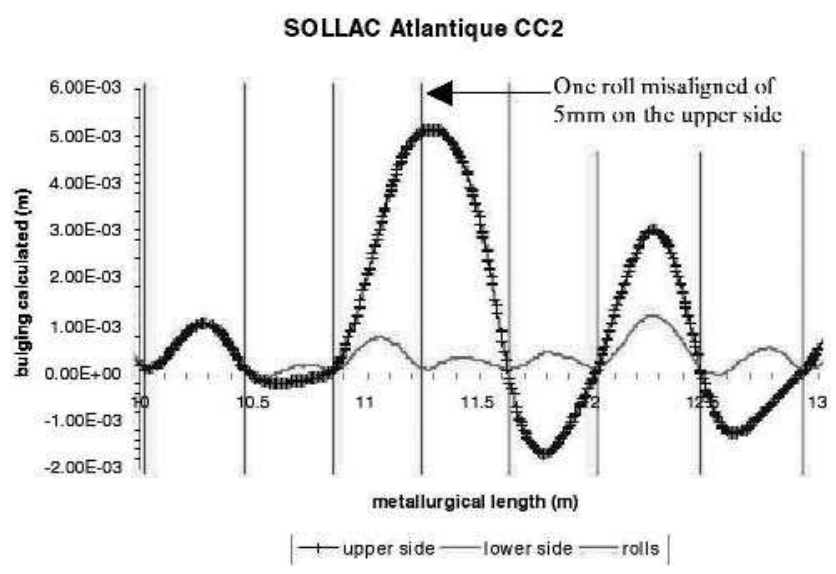

Fig. 10 - A roll misalignment strongly disturbs the bulging profile in following roll pitches.

Fig. 10 - Le désalignement d'un rouleau perturbe fortement le profil de gonflement de la brame dans les rouleaux suivants.

TABLE IV : Position of the maximal bulging according with the casting speed. $L_{0}$ is the roll pitch.

TABLEAU IV : Position du pic de gonflement maximal en fonction de la vitesse de coulée. $L_{0}$ est le pas entre les rouleaux.

\begin{tabular}{|l|c|c|}
\hline & $0.9 \mathrm{~m} / \mathrm{min}$ & $1.2 \mathrm{~m} / \mathrm{min}$ \\
\hline $\begin{array}{l}\text { Position of the maximal bulging } \\
\text { from the upstream roll }\end{array}$ & $0.5 L_{0}$ & $0.6 L_{0}$ \\
\hline
\end{tabular}


SOLLAC Atlantique CC2s

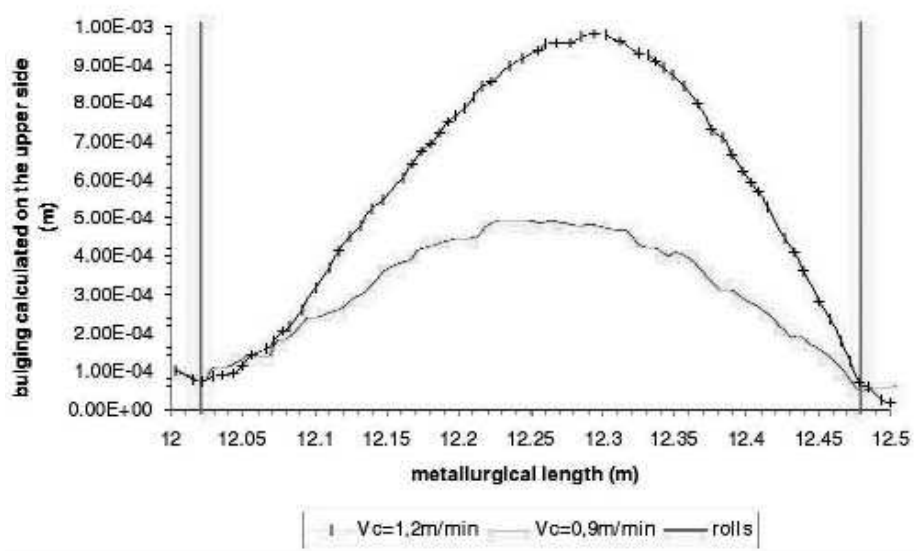

Fig. 11 - When the casting speed increases from $0.9 \mathrm{~m} / \mathrm{min}$ to $1.2 \mathrm{~m} / \mathrm{min}$, the position of the maximal bulging is shifted towards the downstream roll.

Fig. 11 - Quand la vitesse de coulée augmente de $0.9 \mathrm{~m} / \mathrm{min}$ à $1.2 \mathrm{~m} / \mathrm{min}$, la position du pic de gonflement maximal est décalée vers le rouleau aval.

Finally, we focus on the slab bulging calculated between 12 and $12.5 \mathrm{~m}$ with a perfect roll alignment (fig. 11). We can notice that the maximum bulging is shifted towards the downstream roll when the casting speed increases. Table IV presents the position of the maximum bulging, calculated according to the casting speed. It confirms the observations of Wunnenberg (17) and Lamant (18). This bulging profile during steady state casting conditions results from both the downward extraction of the product, and the creep mechanism involved.

\section{INFLUENCE OF PROCESS PARAMETERS ON SLAB BULGING}

Some simulations were carried out on Sollac Méditerranée No. 2 continuous caster. It is a vertical - bending machine with split rolls. The composition of the cast steel grade is the same as the one indicated in table I. We studied the influence

TABLE V : Average bulging calculated on Sollac Mediterranée CC2, before and after revamping, between 8 and $15 \mathrm{~m}$ of metallurgical length. The use of split rolls reduces by about $50 \%$ the bulging at the mid-width of the slab.

TABLEAU V : Gonflement moyen calculé entre 8 et $15 \mathrm{~m}$ de longueur métallurgique, sur la CC2 de Sollac Méditerranée, avant et après la rénovation effectuée en 2002. L'utilisation de rouleaux divisés permet de réduire de moitié le gonflement au milieu des grandes faces.

\begin{tabular}{|c|c|c|}
\hline & Before revamping & After revamping \\
\hline Upper side & $0.322 \mathrm{~mm}$ & $0.182 \mathrm{~mm}$ \\
Lower side & $0.327 \mathrm{~mm}$ & $0.195 \mathrm{~mm}$ \\
\hline
\end{tabular}

of process parameters like molten steel superheat, roll diameter and pitch, cooling strategy, casting speed, on the slab bulging between 8 and $15 \mathrm{~m}$ of metallurgical length.

\section{Benefit of split rolls to reduce slab bulging}

We know that using split rolls reduces slab bulging. It is justified by the fact that a decrease of roll diameter allows a decrease of roll pitch $\left(L_{0}\right)$. This favourable trend is reinforced by the associated decrease of the pitch creep time $\left(\Delta \mathrm{t}_{\text {creep }}\right): \Delta \mathrm{t}_{\text {creep }}=L_{0} / V_{\mathrm{c}}$. This was verified with the model by simulations carried out on both configurations of Sollac Méditerranée CC2, before and after the revamping (19). This revamping has consisted in replacing the big rolls in the low part of the caster by split rolls : the roll diameter was reduced by $100 \mathrm{~mm}$. Only the caster geometry was changed in these simulations. The casting speed is $1 \mathrm{~m} / \mathrm{min}$. Table $V$ points out that the use of split rolls reduces, by about $50 \%$, the bulging at the mid-width of the slab.

\section{Influence of casting speed and cooling strategy on slab bulging}

For a given cooling strategy, we carried out three simulations on the revamped geometry with different casting speeds : $1 \mathrm{~m} / \mathrm{min}, 1.25 \mathrm{~m} / \mathrm{min}$ and $1.5 \mathrm{~m} / \mathrm{min}$. The results indicate that an increase of casting speed induces an increase of slab bulging (fig. 12), despite the reduction of the pitch creep time. Actually this is explained by the fact that an increase of casting speed induces an increase of the slab surface temperature, and a reduction of the thickness solidified : the end of solidification is delayed when we cast faster. For this reason, the solid shell offers less resistance to the ferrostatic pressure loading and creeps more. This was confirmed by the following results where we checked the influence of cooling strategy on slab bulging. Actually, we simulated the casting of the same steel grade at $1.25 \mathrm{~m} / \mathrm{min}$ on Sollac Méditerranée CC2 for two different cooling strategies : one hard and one soft. We notice a reduction of slab bulging when the cooling is intensified (table VI).

TABLE VI : Average bulging calculated on Sollac Mediterranée CC2 between 8 and $15 \mathrm{~m}$ of metallurgical length, for one casting speed of $1.25 \mathrm{~m} / \mathrm{min}$ and for two cooling strategies, one soft and one hard.

TABLEAU VI : Gonflement moyen calculé entre 8 et $15 \mathrm{~m}$ de longueur métallurgique, sur la CC2 de Sollac Méditerranée, pour une vitesse de coulée de $1,25 \mathrm{~m} / \mathrm{min}$, et pour deux conditions de refroidissement, une faible et une forte.

\begin{tabular}{|l|c|c|}
\hline & Hard cooling & Soft cooling \\
\hline Upper side & $0.161 \mathrm{~mm}$ & $0.220 \mathrm{~mm}$ \\
Lower side & $0.187 \mathrm{~mm}$ & $0.231 \mathrm{~mm}$ \\
\hline
\end{tabular}


TABLE VII : Average bulging calculated on Sollac Mediterranée CC2 between 8 and $15 \mathrm{~m}$ of metallurgical length for two superheats, 10 and $30^{\circ} \mathrm{C}$. The effect of superheat on bulging is negligible in the lower part of the caster.

TABLEAU VII : Gonflement moyen calculé entre 8 et $15 \mathrm{~m}$ de longueur métallurgique sur la CC2 de Sollac Méditerranée, pour deux surchauffes : 10 et $30^{\circ} \mathrm{C}$ L'influence de la surchauffe sur le gonflement est négligeable dans la partie basse de la machine.

\begin{tabular}{|l|c|c|}
\hline & Superheat $=10^{\circ} \mathrm{C}$ & Superheat $=30^{\circ} \mathrm{C}$ \\
\hline Upper side & $0.182 \mathrm{~mm}$ & $0.192 \mathrm{~mm}$ \\
Lower side & $0.195 \mathrm{~mm}$ & $0.202 \mathrm{~mm}$ \\
\hline
\end{tabular}

Consequently, a more intensive cooling could offset the increase of bulging induced by an increase of casting speed.

For the soft cooling strategy, and for a casting speed of $1 \mathrm{~m} / \mathrm{min}$, we checked also the influence of molten steel superheat on slab bulging. We observed that an increase of the average slab bulging induced by an increase of the superheat is negligible between 8 and $15 \mathrm{~m}$ of metallurgical length (table VII). This is not the case just below mould exit, where superheat has more influence on the slab surface temperature and the thickness solidified.

This parametric study confirms the results of Lamant (18) who showed that the two main important parameters controlling the intensity of bulging are the roll pitch and the solid shell thickness. The results are also coherent with those of Wunnenberg (17), Miyazawa (20) and Ha (21). For instance, $\mathrm{Ha}(21)$ simulated the bulging of a $0.08 \% \mathrm{C}$ grade slab, cast at $1.4 \mathrm{~m} / \mathrm{min}$. The slab thickness is $250 \mathrm{~mm}$. They calculated a bulging of $0.22 \mathrm{~mm}$ at $15 \mathrm{~m}$ of metallurgical length. If we look at figure 12 , we predict a bulging between 0.18 and $0.20 \mathrm{~mm}$ for the same casting speed. This slight difference could be justified :

\section{SOLLAC Méditerrane CC2}

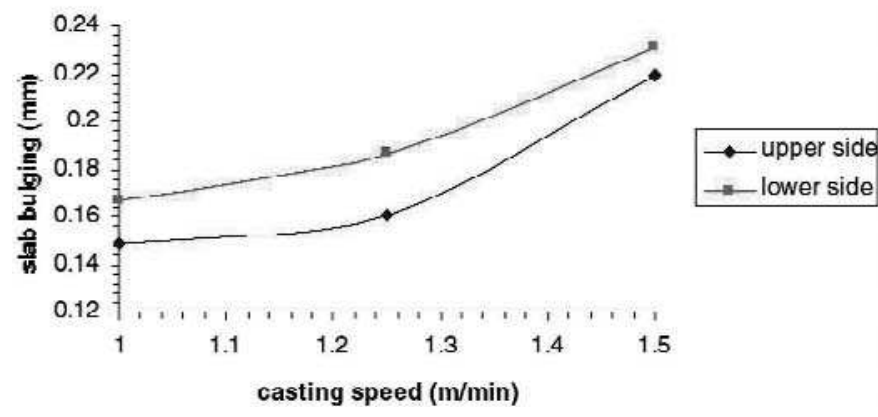

Fig. 12 - The average bulging calculated on Sollac Méditerranée CC2 between 8 and $15 \mathrm{~m}$ of metallurgical length increases with the casting speed.

Fig.12 - Le gonflement moyen calculé entre 8 et $15 \mathrm{~m}$ de longueur métallurgique, sur la CC2 de Sollac Méditerranée, augmente avec la vitesse de coulée.
- we did not use the same rheological models to describe the solid shell behaviour. For instance, they did not take into account strain hardening, which is probably not negligible at $900^{\circ} \mathrm{C}$;

- the slab thickness is $30 \mathrm{~mm}$ more important in their case ;

- at $15 \mathrm{~m}$ of metallurgical length, the roll pitch is $40 \mathrm{~mm}$ lower in Sollac Méditerranée CC2.

This study allowed us to check that the simulation is able to describe accurately the influence of process parameters on slab bulging. The results are very encouraging. Nevertheless, slab bulging is also strongly influenced by the rheological properties of steel. We know that bulging is more pronounced for steels with large Si contents and for ferritic stainless steels. Since steel properties are not well known for the specific conditions existing in the solid shell, it may be difficult to predict absolute values of bulging. Qualitative predictions on the influence of various parameters are, however, possible. The rheological data usually used in this kind of simulation generally come from tensile creep tests under a constant loading $(22,23)$. Such experimental data could be applied directly to calculate the solid shell strain and stress at rest. The case of a moving slab is more complicated because the stress in each moving volume changes with time. The solid phase behaviour under continuously changing loads has not been investigated experimentally according to our knowledge. However, further work will be carried out in order to compare temperature and bulging predictions with measurements performed on the Arcelor Research small slab pilot caster.

\section{- CONCLUSION}

An original macroscopic approach to the thermomechanical stress-strain analysis of steel continuous casting has been developed and was implemented in 2D and 3D finite element software in order to calculate the strains and stresses affecting the slab. The actual caster shape and steel grade properties are accounted for. The accuracy of this approach was qualitatively demonstrated on industrial cases. We showed that the simulation describes successfully the fact that the solidified shell behaves like a beam resting on the support rolls, and creeps due to ferrostatic pressure loading. In addition, we proved the qualitative accuracy of the model to simulate the thermomechanical behaviour of the slab during casting in secondary cooling. It is a useful tool to help manufacturers modify their design of machines and steelmakers adapt their operating conditions according to the cast steel grade properties. In particular, it will be used to :

- predict the adequate operating point for the different continuous casters of Arcelor,

- compare their potentialities to define the optimal metallurgical routes,

- give recommendations for the revamping of the oldest machines. 
Liste of symboles / Liste des symboles

\begin{tabular}{|lll|lll}
\hline$T$ & ${ }^{\circ} \mathrm{C}$ & Temperature & $\varepsilon_{\mathrm{r}}$ & & Steel emissivity \\
$T_{\text {ext }}$ & ${ }^{\circ} \mathrm{C}$ & External temperature & $\sigma_{\mathrm{r}}$ & $\mathrm{W} / \mathrm{m}^{2} / \mathrm{K}^{4}$ & Stephan-Boltzmann constant \\
$T_{\mathrm{C}}$ & ${ }^{\circ} \mathrm{C}$ & Coherency temperature & $V_{\mathrm{C}}$ & $\mathrm{m} / \mathrm{s}$ & Casting speed \\
$H$ & $\mathrm{~J} / \mathrm{kg}$ & Enthalpy & $\sigma_{\mathrm{XX}}$ & $\mathrm{Pa}$ & Transverse stresses \\
$\rho$ & $\mathrm{Kg} / \mathrm{m}^{3}$ & Density & $\sigma_{\mathrm{YY}}$ & $\mathrm{Pa}$ & Longitudinal stresses \\
$\lambda$ & $\mathrm{W} / \mathrm{m} /{ }^{\circ} \mathrm{C}$ & Thermal conductivity & $\sigma_{\mathrm{XY}}$ & $\mathrm{Pa}$ & Shear stresses \\
$C_{\mathrm{p}}$ & $\mathrm{J} / \mathrm{kg} /{ }^{\circ} \mathrm{C}$ & Specific heat & $L_{0}$ & $\mathrm{~m}$ & Roll pitch \\
$g_{\mathrm{s}}$ & & Volume fraction of solid & $\Delta \mathrm{t}_{\mathrm{creep}}$ & $\mathrm{s}$ & Pitch creep time \\
$L$ & $\mathrm{~J} / \mathrm{kg}$ & Specific latent heat of fusion & $\mathbf{n}$ & & Outward normal unit vector \\
$\Phi_{\text {imp }}$ & $\mathrm{W} / \mathrm{m}^{2}$ & Imposed density of heat flux & $\mathbf{g}$ & & Gravity vector \\
$h_{\text {zone }}$ & $\mathrm{W} / \mathrm{m}^{2} /{ }^{\circ} \mathrm{C}$ & Average heat transfer coefficient . & $\sigma$ & & Cauchy stress tensor \\
& & on one zone & & & \\
\hline
\end{tabular}

Following Kajitani (24), our final objective consists in being able to predict the formation of axial macrosegregation and hot tears according with the steel grade properties and the operating conditions. It will be useful, for instance, to define the adequate mechanical soft reduction. To achieve this goal, the one-phase approach to describe the mushy zone is very rough. A more accurate description is developed and will be coupled to the present 2D modelling (12). We account for heat, mass, momentum and solute exchange between the solid phase and the liquid phase into the mushy zone. We make a clear distinction between the motion of the liquid phase and of the solid phase. This approach needs also accurate data to describe the deformation of the compressible semi-solid domain. Many experimental investigations have been carried out to study mushy zone rheology, but they were mainly focused on $\mathrm{Sn}-\mathrm{Pb}(25)$ and $\mathrm{Al}$ alloys (26).

On the contrary, the $3 \mathrm{D}$ modelling is dedicated to solve surface quality issues. We have the possibility to calculate local heat release in the secondary cooling due to roll contact and spray cooling. It is interesting to simulate the thermomechanical behaviour of the slab corners in order to reduce corner crack ratios. Moreover, we have begun to develop a non-steady 3D numerical modelling of the thermomechanical behaviour of the shell solidified in a slab continuous casting mould. This model will fully couple the turbulent, transient molten steel flow in the inlet nozzle and the strand liquid pool, with the thermomechanical behaviour of the shell that solidifies, and the distortion of the mould copper plates.

\section{ACKNOWLEDGEMENT}

The authors would like to acknowledge the financial support of the Ministère de l'Économie, des Finances et de l'Industrie, in the frame of the OSC - Continuous Casting project, and all their partners : Transvalor, Sciences \& Computer Consultants and Ascometal-Lucchini. We are also grateful to Professor Gérard Lesoult from École des Mines de Nancy for his valuable advices.

\section{REFERENCES}

(1) BOBADILLA (M.), JOLIVET (J.-M.), LAMANT (J.-Y.), LARRECQ (M.) - Continuous casting of steel : A close connection between solidification studies and industrial process development. Materials Sciences and Engineering, A173 (1993), p. 275-285.

(2) MIYAZAWA (K.), SCHWERDTFEGER (K.) - Macrosegregation in continuously cast steel : Preliminary theoretical investigation on the effect of steady state bulging. Arch. Eisenhüttenwes., 52 (1981), p. 415-422.

(3) LESOULT (G.), SELLA (S.) - Analysis and prevention of centreline segregation during continuous casting of steel related to deformation of the solid phase. Proceedings of the 6th International Iron and Steel Congress, Nagoya, ISIJ, vol. 1 (1990), p. 681-688.

(4) SAEKI (T.), IMURA (H.), OONISHI (Y.), NIIMI (H.), MIWA (E.), YOSHIDA (T.), IGARI (S.), KITAMINE (S.) - Effect of bulging and solidification structure on segregation in continuously cast slab. Transactions ISIJ, 24, No. 11 (1984), p. 907-916.

(5) WON (Y.-M.), YEO (T.-J.), SEOL (D.-J.), OH (K.-H.) A new criterion for internal crack formation in continuously cast steels. Metallurgical and Materials Transactions B, vol. 31B (2000), p. 779-794.

(6) CASTAGNE (S.), HABRAKEN (A.-M.) - Investigation of transverse cracks initiation in continuous steel casting using a finite element approach. Intern. Conference on "Computational and experimental engineering and sciences", Corfu, Greece (2003).

(7) HEINRICH (A.) - Modélisation thermomécanique de la coulée continue d'acier en deux dimensions. PhD thesis, École des Mines de Paris (2003).

(8) COSTES (F.) - Modélisation thermomécanique tridimensionnelle par éléments finis de la coulée continue d'aciers. $\mathrm{PhD}$ Thesis, École des Mines de Paris (2004).

(9) BELLET (M.), HEINRICH (A) - A two-dimensional finite element thermomechanical approach to a global stressstrain analysis of steel continuous casting. ISIJ International, 44, No. 10 (2004), p. 1686-1695. 
(10) THOMAS (B.-G.), STORKMAN (W.-R.), MOITRA (A.) 6th International Iron and Steel Congress, ISIJ, Tokyo (1990), p. 348.

(11) PASCON (F.) - 2D1/2 thermal-mechanical model of continuous casting of steel using finite element method. $\mathrm{PhD}$ Thesis, University of Liège, Belgium (2003).

(12) BELLET (M.), LE CORRE (S.), FACHINOTTI (V.-D.) A 2-phase finite element model to study concurrent fluid flow and solid deformation occurring in mushy zones during the solidification of metallic alloys, Intern. Conference on "Semi-solid processing of alloys and composites", Limassol, Cyprus (2004).

(13) WINTZ (M.), BOBADILLA (M.), LEHMANN (J.), GAYE (H.) - Experimental study and modelling of the precipitation of non-metallic inclusions during solidification of steel. ISIJ International, 35, No. 6 (1995), p. 715-722.

(14) HARDIN (R.-A.), LIU (K.), KAPOOR (A.), BECKERMANN (C.) - A transient simulation and dynamic spray cooling control model for continuous steel casting. Metallurgical and Materials Transactions B, 34B (2003), p. 297-306.

(15) BELLET (M.), JAOUEN (O.) - Finite Element approach to thermomechanics of solidification processes. Intern. conference on "Cutting edge of computer simulation of solidification and casting", Osaka, The Iron and Steel Institute of Japan (1999), p. 173-190.

(16) RAHIER (P.), KRAEMER (R.), LAMANT (J.-Y.), LARRECQ (M.) - Comportement mécanique de la brame dans la zone de refroidissement secondaire d'une machine de coulée continue d'acier. ECSC research project No. 7210 CA/315 (November 1990).

(17) WUNNENBERG (K.) - Strangausbauchung zwischen Stützvollen beim Stransggiessen von Brammen. Stahl und Eisen, Nr. 6 (1978).

(18) LAMANT (J.-Y.), LARRECQ (M.), BIRAT (J.-P.), HENSGEN (J.-L.), WEBER (J.-D.), DHUYVETTER (J.-C.) Study of slab bulging in continuous caster. Conference of the Metals Society, London (1985).

(19) HOSY (P.), MABELLY (P.), PERASSE (T.) - Augmentation de la productivité à la coulée continue $\mathrm{n}^{\circ} 2$ de Sollac Fos. 25es Journées Sidérurgiques Internationales ATS (2004), Session 10, p. 160-161.
(20) MIYAZAWA (K.), SCHWERDTFEGER (K.) - Computation of bulging of continuously cast slabs with simple bending theory. Ironmaking and Steelmaking, No. 2 (1979), p. $68-74$.

(21) HA (J.-S.), CHO (J.-R.), LEE (B.-Y.), HA (M.-Y.) - Numerical analysis of secondary cooling and bulging in the continuous casting of slabs. J. of Materials Processing Technology, 113 (2001), p. 257-261.

(22) WRAY (P.-J.) - Effect of carbon content on the plastic flow of plain carbon steels at elevated temperatures. Metallurgical Transactions A, 13A (1982), p. 125-134.

(23) SUZUKI (T.), TACKE (K.-H.), WUNNENBERG (K.), SCHWERDTFEGER (K.) - Creep properties of steel at continuous casting temperatures. Ironmaking and Steelmaking, 15, No. 2 (1988), p. 90-100.

(24) KAJITANI (T.), DREZET (J.-M.), RAPPAZ (M.) - Numerical simulation of deformation-induced segregation in continuous casting of steel. Metallurgical and Materials Transactions A, 32A (2001), p. 1479-1491.

(25) MARTIN (C.-L.), FAVIER (D.), SUERY (M.), BOBADILLA (M.) - Isothermal constitutive behaviour of the solid-liquid mushy zone, theoretical treatment and experimental identification. Proceedings of Process VIII conference on "Modelling of casting, welding and advanced solidification", TMS edition (1988), p. 875.

(26) LUDWIG (O), COMMET (B.), DREZET (J.-M.), MARTIN (C.), SUERY (M.) - Rheological behaviour of partially solidified Al-Cu alloys : Experimental and numerical study. Proceedings of Process X conference on "Modelling of casting, welding and advanced solidification", TMS edition (2003), p. 183-190. 